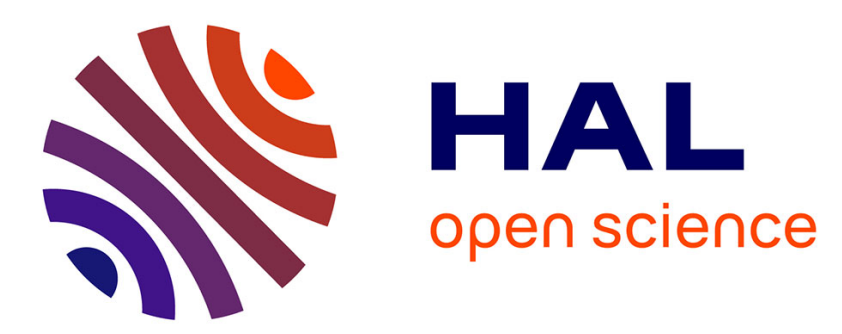

\title{
Envelope treatment of wood based materials with concentrated organosilicons
}

\author{
L. Vetter, J. Bulcke, J. Acker
}

\section{To cite this version:}

L. Vetter, J. Bulcke, J. Acker. Envelope treatment of wood based materials with concentrated organosilicons. European Journal of Wood and Wood Products, 2010, 69 (3), pp.397-406. 10.1007/s00107-010-0448-4 . hal-00615326

\section{HAL Id: hal-00615326 \\ https://hal.science/hal-00615326}

Submitted on 19 Aug 2011

HAL is a multi-disciplinary open access archive for the deposit and dissemination of scientific research documents, whether they are published or not. The documents may come from teaching and research institutions in France or abroad, or from public or private research centers.
L'archive ouverte pluridisciplinaire HAL, est destinée au dépôt et à la diffusion de documents scientifiques de niveau recherche, publiés ou non, émanant des établissements d'enseignement et de recherche français ou étrangers, des laboratoires publics ou privés. 


\title{
Envelope treatment of wood based materials with concentrated organosilicons
}

\author{
L. De Vetter, J. Van den Bulcke*, J. Van Acker \\ Ghent University, Faculty of Bioscience Engineering, Laboratory of Wood \\ Technology \\ Coupure Links 653 \\ B-9000 Gent, Belgium \\ * Corresponding author \\ Jan.VandenBulcke@UGent.be
}

\begin{abstract}
Counteracting moisture ingress in wood and wood based products is crucial for service life prolongation. The use of solvent- as well as water-based organosilicons as envelope treatments on such materials is investigated. Therefore, organosilicons were applied onto four different substrates like OSB and MDF as well as solid wood and plywood. Both treated as well as untreated materials were subjected to a series of floating and imbibition protocols in combination with artificial weathering in order to quantify their hydrophobing action. Envelope treatments of organosilicons show potential in improving water repellent characteristics of solid wood and plywood but have a reduced effectiveness after artificial weathering. The wood based panels OSB and MDF behave opposite. Further research is needed to validate hypotheses on this.
\end{abstract}

\section{Oberflächenbehandlung von Holzwerkstoffen mit konzentrierten Organosiloxanen}

\section{Zusammenfassung}

Um die Nutzungsdauer von Holz und Holzwerkstoffen zu verlängern, ist es wichtig, der Aufnahme von Feuchtigkeit entgegenzuwirken. Untersucht wird die Verwendung von lösemittel- sowie wasserbasierten Organosiloxanen zur Oberflächenbehandlung dieser Materialien. Dazu wurden Organosiloxane auf vier verschiedene Werkstoffe, nämlich OSB und MDF sowie Massivholz und Sperrholz, aufgetragen. Sowohl behandelte als auch unbehandelte Proben wurden einer Reihe von Wasserlagerungs- und Tauchversuchen und künstlicher Bewitterung unterzogen, um die hydrophobierende Wirkung zu bestimmen. Die Oberflächenbehandlung mit Organosiloxanen zeigte Potential, die wasserabstoßenden Eigenschaften von Massivholz und Sperrholz zu verbessern, 
allerdings mit reduzierter Wirkung nach künstlicher Bewitterung. OSB und MDF verhalten sich entgegengesetzt. Zur Bestätigung dieser Hypothesen sind weitere Untersuchungen erforderlich. 


\section{Introduction}

Wood and wood products are susceptible to physical and biological degradation when exposed outdoors. Moisture plays an important role in this degradation process. Lowering the water and water vapour uptake is one method to protect the material. This can be accomplished by modifying the material, making it less hydrophilic or by creating a protective envelope around it, inhibiting moisture ingress.

Since organosilicons are hydrophobing agents, they are supposed to interact in the woodwater relationship, leading to lower moisture uptake by the wood products. This should be beneficial for the service life of the wooden commodity. Donath et al. (2006) reported that silanes have a positive effect on water repellence and Hager (1995) found a reduction of water uptake by $70 \%$ for silicone treated spruce. Previously limited evidence was found that organosilicons applied at low concentrations lead to lower water sorption (both liquid and water vapour) of wood, especially when tested and evaluated under laboratory conditions (De Vetter 2009). Higher concentrations of organosilicons increase protection, but since De Vetter et al. (2009) have already indicated that these concentrations are no longer economically feasible for full wood matrix treatment, the application was limited to the envelope or the edges of the material.

Although moisture related properties of wood based products and the effects of envelope treatments on them have been investigated before, no literature references were found concerning the influence of organosilicons as envelope treatments on these building materials. It was considered valuable to investigate whether organosilicons, when applied at high concentrations, could induce a change in the wood-water relationship. Therefore, all treated and untreated specimens were subjected to a series of floating and imbibition tests in combination with artificial weathering. Solid wood is often applied under use class 3 conditions, whereas swelling of the edges of wood based panels may occur when applied as e.g. wood flooring.

\section{Materials and methods}

\section{Wood materials and organosilicon products}

In addition to solid Scots pine sapwood (Pinus sylvestris L.), four kinds of plywood and some wood based materials like medium density fiberboard (MDF) and oriented strand 
board (OSB) were included. While the MDF-HLS was glued with melamine urea formaldehyde resin (MUF), the OSB/3 was glued with polymeric diphenylmethane isocyanate (pMDI) (EN 13986, 2002). The plywoods were made of poplar (11 plies, 15 $\mathrm{mm}$ thick), spruce (5 plies, $15 \mathrm{~mm}$ thick), birch (11 plies, $15 \mathrm{~mm}$ thick) and maritime pine (7 plies, $17 \mathrm{~mm}$ thick). All plywoods were glued with phenol formaldehyde glue (PF), except for poplar plywood which was glued with MUF.

A broad range of water- and solvent-based organosilicons was applied. An overview of their components and active ingredient concentration is given in Table 1. Micro-emulsion W4 was purchased from Wacker-Chemie GmbH (Germany) and all other organosilicons were obtained from Dow Corning Corporation (Seneffe, Belgium).

To obtain highly concentrated envelope treatments, the organosilicons were brush applied twice onto the wood substrates as supplied (without dilution). Weighing the specimens prior to and after brushing yields the product retention (Eq. 1).

$$
\text { product }_{\text {ret }}\left(\mathrm{g} / \mathrm{m}^{2}\right)=\frac{m_{\text {after application }}(\mathrm{g})-m_{\text {before application }}(\mathrm{g})}{\operatorname{area}\left(\mathrm{cm}^{2}\right)}
$$

\section{Floating test - envelope experiment (focus on Scots pine sapwood)}

The organosilicons W1, W2, W3, W4, W5, S1, and S2 were brushed twice onto Scots pine sapwood specimens measuring $40 \times 15 \times 320 \mathrm{~mm}^{3}(\mathrm{R} \times \mathrm{T} \times \mathrm{L})$. OSB specimens $(18$ $\mathrm{mm}$ thick) were treated with W2 or W4, while the plywood specimens were only treated with organosilicon W2. All boards and half of the Scots pine sapwood specimens were conditioned at $20{ }^{\circ} \mathrm{C}$ and $65 \% \mathrm{RH}$, while the other half of the Scots pine sapwood specimens was conditioned until fiber saturation point (FSP) prior to treatment. Since Mukhopadhyaya et al. (2002) proved that the liquid moisture coefficient of wood (eastern white pine) is temperature dependent all handling was performed in a conditioned room $\left(20{ }^{\circ} \mathrm{C}, 65 \% \mathrm{RH}\right)$. Next, the specimens, sealed at all edges, were floated onto demineralised water. At fixed intervals up to four hours the increase in mass was recorded after blotting of the specimens on drying tissue. Finally, the specimens were removed from the water and put with their longest coated face onto a rack, allowing desorption to occur at $20^{\circ} \mathrm{C}$ and $65 \% \mathrm{RH}$.

After one night of desorption, the mass of the specimens was determined again.

Subsequently, the specimens were weathered in a UV cabinet with spray option (ATLAS UVCON). The first weathering cycle was a so-called wet cycle A. During this cycle the specimens were illuminated $(\lambda=340 \mathrm{~nm})$ for 23 hours in combination with 1 hour 
without illumination; this 24 -hour cycle was then repeated. The spray nozzles were turned on and off according to the diagram shown in Figure 1. After 144 hours the specimens were subjected to a second floating test, followed by a dry artificial weathering cycle B and consecutively a third floating test. During the weathering cycle B the specimens were illuminated constantly while the spray nozzles followed the spraying regime as depicted in Figure 1. The floating test consisted of a 4 hour sorption period, followed by 20 hours of desorption under conditioned circumstances $\left(20^{\circ} \mathrm{C}, 65 \% \mathrm{RH}\right)$. The specimens were weighed after $5 \mathrm{~s}, 5,10 \mathrm{~min}, 1,2,4,5$, and 24 hours. This process of alternating floating and weathering was performed several times. At the end of the experiment, the specimens were oven $\operatorname{dried}\left(103^{\circ} \mathrm{C}\right)$, allowing to calculate the moisture content at each interval (Eq.2).

$$
M C_{t}(\%)=\frac{m_{t}(g)-m_{103^{\circ} \mathrm{C}}(g)}{m_{103^{\circ} \mathrm{C}}(g)} \times 100
$$

\section{Imbibition test - concentrated edge experiment (focus on wood based panels)}

Supplementary to this transverse water sorption and desorption, an imbibition test was performed starting with concentrated edge treatments. In this test set-up small blocks measuring $15 \mathrm{~mm}$ wide and $50 \mathrm{~mm}$ long (Figure 2) were cut from at least three MDF boards (15 mm thick), three OSB boards (18 $\mathrm{mm}$ thick) and three boards of the four plywood types (15 or $17 \mathrm{~mm}$ thick). As reference, Scots pine sapwood specimens ( $15 \times$ $15 \times 50 \mathrm{~mm}^{3}, \mathrm{R} \times \mathrm{T} \times \mathrm{L}$ ) were included. Lukowsky et al. (1998) proved that sealing the side edges of solid wood blocks or treating them with a water repellent prevented superficial creeping at the sides. Therefore, water penetrated the samples only via the unsealed areas in direct contact with water. Since it was the purpose to simulate full size boards and evaluate the protective effectiveness of the water repellents only on the exposed side, all surfaces except for the exposed side and its opposite side were sealed with two coats of a white two-component polyurethane edge sealant system. This opposite side was left unsealed, to avoid pressure build-up of entrapped air which might slow down the water absorption (Candanedo and Derome 2005) (Figure 2).

After conditioning at $20{ }^{\circ} \mathrm{C}$ and $65 \% \mathrm{RH}$, one of the two unsealed edges of each block was brushed twice with one of the pure products W2, W3 or W5. Consequently the specimens were subjected to an imbibition experiment simulating the water absorption caused by wind-driven rain on the façade or exterior cladding of a building envelope 
(Mukhopadhyaya et al. 2002). Therefore, the specimens were put with their treated edge onto a stainless steel grid in contact with a shallow layer of demineralised water, this way avoiding internal pressure (Lukowsky et al. 1998; Candanedo and Derome 2005). The mass and width of each specimen was determined prior to water contact and after $5 \mathrm{~s}, 5$, $10 \mathrm{~min}, 1,2$ and $4 \mathrm{~h}$. The specimens were removed from the water after 4 hours of sorption and allowed to dry under constant temperature $\left(20^{\circ} \mathrm{C}\right)$ and humidity conditions (65\% RH). They were reweighed and measured after 1, 20 and $44 \mathrm{~h}$ desorption. All these values were then used to calculate the MC (Eq. 2), the water repellent effectiveness WRE based on relative water uptake (RWU) (Eqs. 3 and 4) and the swelling in the middle of each specimen (Eq. 5) at different times t.

$$
\begin{gathered}
W R E(\%)=\frac{R W U_{\text {untreated }}-R W U_{\text {treated }}}{R W U_{\text {untreated }}} \times 100 \\
R W U(\%)=\frac{m_{\text {wet }}(g)-m_{d r y}(g)}{m_{\text {dry untreated }}(g)} \times 100 \\
\text { swelling }_{t}(\%)=\frac{\text { width }_{t}(\mathrm{~mm})-\text { width }_{t_{0}}(\mathrm{~mm})}{\text { width }_{t_{0}}(\mathrm{~mm})}
\end{gathered}
$$

During sorption water penetrates the wood block by different forms of diffusion and capillary forces (de Meijer and Militz 2000; Mukhopadhyaya et al. 2002). The moisture moves up in the block and finally reaches the opposite side. From that moment the wood block is capillary saturated and moisture absorption is the result of diffusion, dissolution and removal of air inclusions in the water (Mukhopadhyaya et al. 2002; Roels et al. 2004; Hens 2007). These two phases can clearly be distinguished from each other when the water influx per square meter contact surface is plotted versus the square root of time. Both phases have a linear relationship being typical for hygroscopic porous materials, but with a distinctly different slope (Krus et al. 1997). The intersection defines the capillary saturated volumetric moisture content $\mathrm{w}_{\mathrm{c}}\left(\mathrm{kg} / \mathrm{m}^{3}\right)$ and is a net material property. The slope of the curve in the first phase is called the water absorption coefficient $A_{w}\left[\mathrm{~kg} /\left(\mathrm{m}^{2} \mathrm{~s}^{1 / 2}\right)\right]$ and is a composite property indicating how easily a material absorbs water. When in direct contact with liquid water, this water absorption coefficient determines, together with the moisture-liquid diffusivity $\mathrm{D}_{\mathrm{w}}\left(\mathrm{m}^{2} / \mathrm{s}\right)$, the moisture transport and the redistribution of the moisture into the wood (Mukhopadhyaya et al. 2002). When assuming constant diffusivity and taking the shape of the advancing moisture front into consideration these two parameters can be linked to each other as given in Equation 6 (Kumaran 1999; Mukhopadhyaya et al. 2002; Candanedo and Derome 2005). Although liquid diffusivity $\mathrm{D}_{\mathrm{w}}$ is assumed to be constant, Mukhopadhyaya et al. (2002) proved that 
$D_{w}$ of untreated eastern white pine increased with increasing temperature. That is why this test set-up was performed under constant climatic conditions $\left(20^{\circ} \mathrm{C}\right.$ and $\left.65 \% \mathrm{RH}\right)$. Since $A_{w}$ might be influenced by the superficial treatment with organosilicons it was calculated according to Equation 7 (Kumaran 1999; Candanedo and Derome 2005).

$$
\begin{gathered}
D_{w}\left(\mathrm{~m} / \mathrm{s}^{2}\right)=\frac{\pi}{4}\left[\frac{A_{w}\left(\mathrm{~kg} /\left(\mathrm{m}^{2} \mathrm{~s}^{1 / 2}\right)\right)}{w_{c}\left(\mathrm{~kg} / \mathrm{m}^{3}\right)}\right]^{2}(6) \\
A_{w}\left(\mathrm{~kg} /\left(\mathrm{m}^{2} \mathrm{~s}^{1 / 2}\right)\right)=\frac{m_{\text {time }}(\mathrm{kg})-m_{\text {initial }}(\mathrm{kg})}{\text { contact area } \times \sqrt{\text { time }}\left(\mathrm{m}^{2} \mathrm{~s}^{1 / 2}\right)}
\end{gathered}
$$

\section{Results}

\section{Floating test - envelope experiment with Scots pine sapwood}

The product retentions of the envelope treatment of Scots pine sapwood are given in Table 2. The specimens were floated onto demineralised water prior to and after weathering for one week $(144 \mathrm{~h})$ in an ATLAS UVCON. Figure 3 shows that prior to weathering all organosilicons were able to lower the MC significantly, while this was only valid for some of the treatments after weathering.

In the next experiment pure products were applied onto fibre saturated wood. Figure 4 shows the resulting MC over five floating tests alternated with artificial weathering. Water has accumulated in the wood during this process of artificial weathering and floating. Just like in the first floating test prior to weathering all products show their ability to lower the MC of the wood by up to $60 \%$. Afterwards half of the products are losing their effectiveness and the MC is gradually approaching that of untreated Scots pine sapwood. The other products continue to lower the MC by 30 to $70 \%$ even after more than 696 hours of alternating floating and weathering. The solvent-based products S1 and S2 perform best, followed by the emulsions W4 and W5.

Due to the promising results obtained for protecting solid wood, some organosilicons were applied onto the envelope of plywood and OSB. In Figures 5 and 6 the MC during floating prior to and after one cycle of artificial weathering of untreated and organosilicon 
treated plywood and OSB is illustrated. The plywood specimens were brushed twice with product W2, while OSB was treated with either W2 or W4. Figure 5 shows that for OSB only slight improvements (15-30 \%) can be observed, while for plywood (Figure 6) even lower impacts must be noted $(<20 \%)$. However, it must be stressed that for Scots pine sapwood better results were obtained with other organosilicons, indicating that better performance might also be achieved on plywood and OSB when those other organosilicons would have been applied.

\section{Imbibition test - concentrated edge experiment (focus on wood based panels)}

Following the superficial application of organosilicons at high concentrations onto solid wood and wood based panels, a concentrated edge experiment was set up. Table 3 gives the obtained product retentions and shows that for Scots pine sapwood this retention does not differ greatly among the organosilicons, while it does for poplar and birch plywood. These differences are however small compared to the large organosilicon dependent product retentions noted for the wood based materials OSB and especially MDF.

Figures $7 \mathrm{a}$ and $7 \mathrm{~b}$ show the moisture contents and swelling of (un)treated Scots pine sapwood, OSB and MDF. These figures indicate a reduction of moisture content and swelling during sorption and desorption for organosilicon treated Scots pine sapwood, while increased moisture content and swelling is seen for organosilicon treated OSB and MDF compared to their untreated counterparts. Although a fast reduction in moisture content is noted once the specimens were removed from the water, the swelling of most specimens continued for at least another hour.

For plywood the graphs are not univocal (Figures $8 \mathrm{a}$ and $8 \mathrm{~b}$ ). While the MC is lowered when organosilicons were applied, the swelling is only reduced for the products W3 or W5. Application of W2 leads to swelling which is at least as high as the one of untreated plywood. As expected the WRE values for MDF and OSB are negative, while WRE values of 50 to $65 \%$ are observed for Scots pine sapwood after 4 hours sorption. For plywood WRE-values range from 10 to $70 \%$, depending both on the organosilicon applied and on the kind of plywood (data not presented).

Table 4 lists the resulting water absorption coefficients $\left(\mathrm{A}_{\mathrm{w}}\right)$ for untreated and organosilicon treated Scots pine sapwood, plywood, OSB, and MDF. As expected the saturated capillary moisture content $\left(\mathrm{w}_{\mathrm{c}}\right)$ of Scots pine sapwood was not reached within 4 hours of sorption. This means that the sorption was still in the first phase and all data 
points of cumulative inflow versus square root of time were used in the linear regression as the basis for the determination of the water absorption capacity. This was also valid for untreated OSB and MDF. On the other hand, the untreated plywoods reached the saturated capillary moisture content $\left(\mathrm{w}_{\mathrm{c}}\right)$ already after circa 10 to $115 \mathrm{~min}$, depending on the type of plywood. Therefore, a distinction had to be made between the first and second phase of sorption based on visual inspection. Only those points belonging to the first phase were used in the regression analysis for calculation of the water absorption coefficient.

Table 4 shows that all organosilicons lower $A_{w}$ considerably for solid Scots pine sapwood. This is to a lesser extent the case for all plywoods, except for poplar plywood treated with W3. For the three other types of plywood best performance was achieved with product W5, followed by W3 and W2. The reduction of the water absorption coefficient for all three plywoods treated with W5 and maritime pine and spruce plywood treated with $\mathrm{W} 3$ was such that $\mathrm{w}_{\mathrm{c}}$ was not reached within 4 hours of sorption.

In contrast, the wood based materials OSB and MDF behaved opposite. While their $\mathrm{A}_{\mathrm{w}}$ values were the lowest of all untreated specimens, these values increased after application of organosilicons. This increase was so dramatic for OSB treated with W3 and for MDF treated with all organosilicons that they reached the saturated capillary moisture content already after 10 to $70 \mathrm{~min}$.

\section{Discussion}

The results of the envelope treatment confirm the statements for solid wood (De Vetter 2009): (1) organosilicons are able to lower the moisture uptake of treated wood, (2) but the effectiveness of most organosilicons is reduced significantly by weathering. Extrapolation towards wood based materials is however not straightforward. Nofal and Kumaran (1999) examined the behaviour of OSB in a cyclic wetting and drying experiment. They found that sealing the edges of panels reduced the MC by $5 \%$ and slowed down the board thickness increase. This is important since thickness increase affects the volume of air cavity when the boards are used in e.g. a wall assembly and may subsequently affect its functionality.

For the floating test with edge sealed specimens a reduction in $\mathrm{MC}$ of up to $15 \%$ was recorded when the boards were brushed with an organosilicon. However, comparing Figure 5 with Figures 3 and 4 shows that OSB boards in direct contact with water during the floating test have a moisture uptake which is several times higher than for solid Scots 
pine sapwood. In contrast this is not the case when the edges of untreated OSB and MDF are considered and compared to the transverse surface of untreated Scots pine sapwood (Figure 7). Although it is already known that the thickness swell of OSB is higher than the swelling of solid wood due to release of compaction stress created during pressing, this should be seen in its proper context. At the beginning of the edge swelling test, Scots pine sapwood swells fast, but also reaches its maximum soon (Figure 8). OSB and MDF in contrast have a continuous increase in swelling during the whole sorption period and continue to swell at the beginning of the desorption stage. Initially OSB and MDF are less swollen than Scots pine sapwood, but after approximately 2 and 3.5 hours of sorption, respectively, this is reversed. Taking the higher moisture uptake and ultimate increased swelling into consideration, it is not surprising that negative WRE values were recorded for OSB and MDF (data not presented).

It has been proven before that the moisture content of wood based panels exposed to direct wetting is influenced by wetting time and by panel characteristics that affect capillarity such as wood species and wax additives of OSB. Figure 6 shows that the organosilicon W2 (40\% DMS/n-OTES) succeeds in a slight reduction $(<20 \%)$ of the MC of each type of plywood except for birch plywood. Focussing on the edges of the boards, reductions of MC between 5 and $50 \%$ can be achieved, depending on the plywood type and organosilicon applied (Figure 8). The order of magnitude of MC and swelling of plywood during the envelope and edge swelling tests are comparable to that of Scots pine sapwood. In contrast to OSB not all organosilicons succeed in reducing the swelling of plywood. Between the different plywood types differences in MC and swelling are seen, which cannot directly be linked to panel characteristics like wood species, thickness and number of plies, glue type, etc.

As stated above the water absorption coefficient $A_{w}$ governs the liquid moisture movement into a material. For wood used in use class 3 conditions, e.g. cladding as part of a building envelope, it is of utmost importance to determine this water absorption coefficient as it is one of the most important hygrothermal properties necessary to deal with the overall moisture management of a building envelope (Mukhopadhyaya et al. 2002). Up to now $A_{w}$ was determined for coatings as such or coatings applied on wood (Hora 1994; Ahola et al. 1999; de Meijer and Militz 2000) and for untreated softwood (Mukhopadhyaya et al. 2002; Candanedo and Derome 2005; Miniotaite 2005) but not yet for wood treated with organosilicons.

The second sorption stage was not reached for Scots pine sapwood in this edge imbibition test. This means that the moisture content was still below the capillary saturated moisture 
content. Mukhopadhyaya et al. (2002) found a water absorption coefficient at a water bath temperature of $21{ }^{\circ} \mathrm{C}$ of on average $112.0 \cdot 10^{-4} \mathrm{~kg} /\left(\mathrm{m}^{2} \mathrm{~s}^{1 / 2}\right)$. Miniotaite (2005) and Kumaran (1999) both reported an $A_{w}$ value for spruce equal to $96.010^{-4} \mathrm{~kg} /\left(\mathrm{m}^{2} \mathrm{~s}^{1 / 2}\right)$. The water bath temperature was $22{ }^{\circ} \mathrm{C}$ in the first report. Candanedo and Derome (2005) found $A_{w}$ values between $96.6 \cdot 10^{-4}$ and $156 \cdot 10^{-4} \mathrm{~kg} /\left(\mathrm{m}^{2} \mathrm{~s}^{1 / 2}\right)$ for undefined longitudinally sawn softwood. Logically they found lower values for radially $\left[19.410^{-4} \mathrm{~kg} /\left(\mathrm{m}^{2} \mathrm{~s}^{1 / 2}\right)\right]$ or tangentially $\left[26.5 \cdot 10^{-4}-28.6 \cdot 10^{-4} \mathrm{~kg} /\left(\mathrm{m}^{2} \mathrm{~s}^{1 / 2}\right)\right]$ sawn specimens.

The average $A_{w}$ value found in this research $\left[210.5 \cdot 10^{-4} \mathrm{~kg} /\left(\mathrm{m}^{2} \mathrm{~s}^{1 / 2}\right)\right]$ for radial/tangential Scots pine sapwood was in the same order of magnitude, but higher than the previously mentioned values. Application of organosilicons lowers this water absorption coefficient three to six times, but still remains higher than literature values reported for transverse sections of softwood. Ahola et al. (1999) determined water absorption coefficients for coatings on spruce and pine and reported values between circa $50 \cdot 10^{-4}$ and $4010^{-4} \mathrm{~kg} /\left(\mathrm{m}^{2}\right.$ $\mathrm{h}^{1 / 2}$ ), much lower than the obtained values in this research for organosilicon treated wood. This means that coatings are better in reducing the water absorption coefficient of Scots pine than organosilicons. It is suggested that moisture movement through a coating is controlled by diffusion and not by capillarity (Ahola et al. 1999) while capillary liquid flow is important in uncoated wood after longer exposure times (de Meijer and Militz 2000).

The mode of action of the organosilicons may be similar when applied onto earth substrates. As such the silicone can adsorb on the substrate capillaries to form a thin hydrophobic polysiloxane film which can significantly increase the contact angle of water with the substrate capillary wall and reduce the water absorption of the substrate through capillary depression (Noll 1968; Ren and Kagi 1995). Since positive correlations between contact angles of water on coated wood and water absorption rates have been found before, this seems a plausible explanation (Hora 1994; de Meijer and Militz 2000). It was stated before that water repellents, meant to lower the velocity of water uptake and not the maximum water uptake, can cause a reduction of the capillary tension of wood and even a capillary depression (Lukowsky and Peek 1997). De Vetter et al. (2006) found a discontinuous micro-porous network on the cell walls and in the lumens of tracheids and wood rays of Scots pine sapwood after dipping in a low concentrated organosilicon. It can therefore be assumed that highly concentrated organosilicon at the surface could lead to a thin film on the surface, leading to increased contact angle and lower water absorption coefficient. Since the formation of a polysiloxane film could be crucial in explaining the behaviour of the treated material, further investigation should be performed. This can be 
done by doping the organosilicon prior to application and then combining image analysis (SEM or $\mu-\mathrm{CT}$ ) with elementary compositional analysis (EDX) as described in De Vetter et al. (2006). While also wavelength-dispersive spectrometry (Niu et al. 2009) might be used as compositional analysis modality, imaging techniques like confocal microscopy (Van den Bulcke et al. 2003; Singh and Dawson 2004) or X-ray imaging (Van den Bulcke et al. 2010) could be used as well. While the results for plywood follow the same trend as for solid Scots pine, other factors seem to play a role for the wood based panels MDF and OSB. After superficial application of organosilicons they absorb more water than their untreated counterparts. Since the matrices of OSB and MDF are significantly different from those of solid wood, and knowing that their sorption behaviour is different, organosilicons probably act differently on those materials than on solid wood. The altered moisture dynamics of wood based panels after superficial treatment with organosilicons is clearly of interest for future research.

\section{Conclusion}

Superficial treatments at high concentrations show potential in improving water repellent characteristics of solid wood and plywood. Drawback is the reduced effectiveness after artificial weathering. Considering the wood based materials OSB and MDF, organosilicons behaved opposite as expected. They increased the moisture uptake of the edges and consequently the swelling. The mode of action of this process is not yet revealed and forms a challenge for future research.

\section{Acknowledgements}

Since the European Commission supported the research project HYDROPHOB (QLK5-CT-200201439), which was the framework for this study, the authors would like to thank the Commission for the financial support. The authors also wish to thank the Fund for Scientific Research-Flanders (FWO - Belgium) for the postdoctoral funding granted to the second author.

The authors declare that they have no conflict of interest. 


\section{References}

Ahola A, Derbyshire H, Hora G, de Meijer M (1999) Water protection of wooden window joinery with low organic solvent content paints with known composition. Holz Roh- Werkst 57: 45-50

Candanedo L, Derome D (2005) Numerical simulation of water absorption in softwood. In: Proceedings of the Ninth International IBPSA Conference, pp. 123-130

de Meijer. M, Militz H (2000) Moisture transport in coated wood. Part 1: Analysis of sorption rates and moisture content profiles in spruce during liquid water uptake. Holz Roh- Werkst 58: $354-362$

De Vetter L (2009) Organosilicon compounds as potential wood protecting agents. Dissertation, Ghent University

De Vetter L, Cnudde V, Masschaele B, Jacobs PJS, Van Acker J (2006) Detection and distribution analysis of organosilicon compounds in wood by means of SEM-EDX and micro-CT. Mater Char 56: $39-48$

De Vetter L, Stevens M, Van Acker J (2009b) Fungal decay resistance and natural durability of organosilicon treated wood. Int Biodeterior Biodegrad 63: 130-134

Donath S, Militz H, Mai C (2006) Creating water repellent effects on wood by treatment with silanes. Holzforschung 60: 40-46

EN 13986 (2002) Wood-based panels for use in construction - Characteristics, evaluation of conformity and marking

Hager R (1995) Waterborne silicones as wood preservatives. IRG/WP/95-30062. The International Research Group on Wood Protection, Stockholm, Sweden

Hens H (2007) Building physics - Heat, air and moisture. Fundamentals and engineering methods with examples and exercises. Ernst \& Sohn Verlag, Berlin

Hora G (1994) The dynamic contact angle. A characteristic to predict the lifetime of a wood topcoat. J Coat Technol Res 66: 55-59

Krus M, Hansen KK, Künzel HM (1997) Porosity and liquid absorption of cement paste. Mater Struct 30: 394-398 
Kumaran MK (1999) Moisture diffusivity of building materials from water absorption measurements. J Therm Envel Build Sci 22: 349-355

Lukowsky D, Farnow M, Rypstra T (1998) Some aspects of testing water repellents. IRG/WP 9840113. The International Research Group on Wood Protection, Stockholm, Sweden

Lukowsky D, Peek RD (1997) Water-based silicones on wood. IRG/WP/97-30144. The International Research Group on Wood Protection, Stockholm, Sweden

Miniotaite R (2005.) Hygric properties of building materials. In: Prodceedings of the $7^{\text {th }}$ Nordic Symposium on Building Physics, Reykjavík

Mukhopadhyaya P, Kumaran K, Normandin N, Goudreau P (2002) Effect of surface temperature on water absorption coefficient of building materials. J Therm Envel Build Sci 26: 179-195

Niu YR, Liu XY, Zheng XB, Ji H, Ding C (2009) Microstructure and properties characterization of silicon coatings prepared by vacuum plasma spraying technology. J Therm Spray Technol 18 (3): $427-434$

Nofal M, Kumaran K (1999) Behaviour of engineered wood materials under the effect of wetting and drying cycles. In: Proceedings of the 10th International Conference on Building Physics and Building Technology, pp. 193-203

Noll W (1968) Chemistry and technology of silicones. Academic Press Inc, London

Ren KB, Kagi DA (1995) Study of water repellent effect of earth substrates impregnated with water-based silicones. J Chem Technol Biotechnol 63: 237-246

Roels S, Carmeliet J, Hens H, Adan O, Brocken H, Cerny R, Pavlik Z, Hall C, Kumaran K, Pel L, Plagge R (2004) Interlaboratory comparison of hygric properties of porous building materials. J Therm Envel Build Sci 27: 307-325.

Singh AP, Dawson BSW (2004) Confocal microscope - a valuable tool for examining woodcoating interface (Short communication). JCT Research 1:235-237

Van den Bulcke J, Boone M, Van Acker J, Van Hoorebeke L (2010) High-resolution X-ray imaging and analysis of coatings on and in wood. J Coat Technol Res In press 
Van den Bulcke J, Rijckaert V, Van Acker J, Stevens M (2003) Quantitative measurement of the penetration of water-borne coatings in wood with confocal lasermicroscopy and image analysis. Holz Roh- Werkst 61:304-310 
Figure 1: Spray nozzle cycles during 24 hours weathering in an ATLAS UVCON (minutes)

Figure 2: Picture of an edge experiment specimen

Figure 3: Moisture content during sorption (S) and desorption (D) prior to and after artificial weathering (W) of organosilicon treated Scots pine sapwood preconditioned at $20^{\circ} \mathrm{C}$ and $65 \%$ $\mathrm{RH}$

Figure 4: Moisture content during sorption (S), desorption (D) and artificial weathering (W) of organosilicon treated Scots pine sapwood pre-conditioned at fiber saturation point. Weathering consisted of alternating a wetter (Ww) and dryer cycle (Wd)

Figure 5: Moisture content of untreated and with organosilicon W2 or W4 treated OSB during 4 hours sorption (S) and 19 hours desorption (D) prior to and after $144 \mathrm{~h}$ artificial weathering (W)

Figure 6: Moisture content of untreated (continuous line) and with organosilicon W2 treated plywood (dashed line) $4 \mathrm{~h}$ sorption (S) and 19h desorption (D) prior to and after $144 \mathrm{~h}$ artificial weathering $(\mathrm{W})$

Figure 7: (a) Moisture content and (b) edge swelling during sorption (S) and desorption (D) of MDF (M), OSB (O) and Scots pine sapwood (SP), either left untreated or brushed with organosilicons W2, W3 or W5

Figure 8: (a) Moisture content and (b) edge swelling during sorption (S) and desorption (D) of poplar plywood (P P), spruce plywood (P S), Maritime pine plywood (P MP) and birch plywood (P B). The specimens were either left untreated or treated with organosilicons W2, W3 or W5

\author{
Abb. 1 \\ Sprühzyklen bei 24-stündiger Bewitterung in einem ATLAS UVCON-Gerät \\ (Minuten)
}

Abb. 2 Prüfkörper für den Versuch mit Kantenbefeuchtung

\author{
Abb. 3 \\ Holzfeuchteverlauf während der Sorption (S) und Desorption (D) vor und nach \\ künstlicher Bewitterung (W) von mit Organosiloxan behandeltem \\ Kiefernsplintholz, das zuvor bei $20^{\circ} \mathrm{C}$ und $65 \%$ rel. Lf. klimatisiert worden war.
}

Abb. 4 
Holzfeuchteverlauf während der Sorption (S) und Desorption (D) und künstlicher Bewitterung (W) von mit Organosiloxan behandeltem Kiefernsplintholz, das zuvor bis Fasersättigung klimatisiert wurde.

Die Bewitterung wechselte zwischen einem feuchteren $(\mathrm{Ww})$ und einem trockeneren (Wd) Zyklus

\section{Abb. 5}

Holzfeuchteverlauf von unbehandeltem und mit Organosiloxan W2 oder W4 behandeltem OSB bei 4-stündiger Sorption (S) und 19-stündiger Desorption (D) vor und nach 144-stündiger künstlicher Bewitterung (W)

Abb. 6

Holzfeuchteverlauf von unbehandeltem (durchgezogene Linie) und mit Organosiloxan W2 behandeltem Sperrholz (gestrichelte Linie) bei 4-stündiger Sorption (S) und 19-stündiger Desorption (D) vor und nach 144-stündiger künstlicher Bewitterung (W)

Abb. 7

a) Holzfeuchteverlauf und b) Kantenquellung während der Sorption (S) und Desorption (D) von MDF (M), OSB (O) und Kiefernsplintholz (SP), entweder unbehandelt oder mit Organosiloxan W2, W3 oder W5 bestrichen

Abb. 8

a) Holzfeuchteverlauf und b) Kantenquellung während der Sorption (S) und Desorption (D) von Pappelsperrholz (PP), Fichtensperrholz (PS), Strandkiefernsperrholz (PMP) und Birkensperrholz (PB). Die Prüfkörper waren entweder unbehandelt oder mit Organosiloxan W2, W3 oder W5 behandelt.

Tabelle 1

Überblick über die verwendeten Produkte und deren Hauptbestandteile und Wirkstoffkonzentrationen

Tabelle 2 
Produktaufnahme $\left(\mathrm{g} / \mathrm{m}^{2}\right)$ von unterschiedlich klimatisiertem Kiefernsplintholz, das zweimal mit sieben unverdünnten Organosiloxanen bestrichen wurde.

Tabelle 3

Produktaufnahme $\left(\mathrm{g} / \mathrm{m}^{2}\right)$ von Holzwerkstoffen, die zweimal mit unverdünntem Organosiloxan W2, W3 und W5 bestrichen wurden

Tabelle 4

Wasseraufnahmekoeffizient $\mathrm{A}_{\mathrm{w}}\left[10^{-4} \mathrm{~kg} /\left(\mathrm{m}^{2} \mathrm{~s}^{1 / 2}\right)\right]$ von Kiefernsplintholz und verschiedenen Holzwerkstoffen, entweder unbehandelt oder mit den

Organosiloxanen W2, W3 oder W5 bestrichen. Die Werte in Kursivschrift haben während des Versuchs den gesättigten Kapillarfeuchtegehalt $\mathrm{w}_{\mathrm{c}}$ nicht erreicht 
Table 1: Overview of the products used with their main components and active ingredient concentrations

\begin{tabular}{|l|l|l|}
\hline Product code & Main components & Concentration active ingredient (\%) \\
\hline Water-based organosilicons & n-OTES & 40 \\
\hline W1 & DMS/n-OTES & 40 \\
\hline W2 & PDMS & 60 \\
\hline W3 & PDMS/TES & 100 \\
\hline W4 & PDMS & 60 \\
\hline W5 & n-OTES \\
\hline Solvent-based organosilicons & 100 \\
\hline S1 & MTM/n-OTES & 100 \\
\hline S2
\end{tabular}

Table 2: Product retention $\left(\mathrm{g} / \mathrm{m}^{2}\right)$ of Scots pine sapwood pre-conditioned under different circumstances and brushed twice with seven undiluted organosilicons

\begin{tabular}{|l|l|l|}
\hline Organosilicons & $20^{\circ} \mathrm{C}, 65 \% \mathrm{RH}$ & Fiber saturated \\
\hline W1 & - & $145 \pm 21$ \\
\hline W2 & $148 \pm 33$ & $164 \pm 51$ \\
\hline W3 & $215 \pm 54$ & $131 \pm 38$ \\
\hline W4 & $136 \pm 43$ & $115 \pm 41$ \\
\hline W5 & $167 \pm 17$ & $155 \pm 16$ \\
\hline S1 & $179 \pm 16$ & $147 \pm 32$ \\
\hline S2 & $158 \pm 4$ & $141 \pm 34$ \\
\hline
\end{tabular}


Table 3: Product retention $\left(\mathrm{g} / \mathrm{m}^{2}\right)$ of wood based materials brushed twice with the undiluted organosilicons W2, W3 or W5

\begin{tabular}{|l|l|l|l|}
\hline Wood based material & W2 & W3 & W5 \\
\hline Scots pine sapwood & $175 \pm 23$ & $184 \pm 31$ & $134 \pm 15$ \\
\hline Poplar plywood & $295 \pm 40$ & $549 \pm 60$ & $289 \pm 111$ \\
\hline Spruce plywood & $298 \pm 25$ & $705 \pm 52$ & $1368 \pm 149$ \\
\hline Maritime pine plywood & $352 \pm 67$ & $630 \pm 62$ & $547 \pm 90$ \\
\hline Birch plywood & $315 \pm 53$ & $345 \pm 63$ & $296 \pm 92$ \\
\hline OSB & $209 \pm 23$ & $238 \pm 45$ & $213 \pm 24$ \\
\hline MDF & $229 \pm 54$ & $401 \pm 51$ & $329 \pm 35$ \\
\hline
\end{tabular}

Table 4: Water absorption coefficient $A_{w}\left[10^{-4} \mathrm{~kg} /\left(\mathrm{m}^{2} \mathrm{~s}^{1 / 2}\right)\right]$ for different wood materials either untreated or brush-treated with organosilicon W2, W3 or W5. Values given in italics did not reach the saturated capillary moisture content $\mathrm{w}_{\mathrm{c}}$ during the experiment

\begin{tabular}{|l|l|l|l|l|}
\hline $\begin{array}{l}\text { Wood based } \\
\text { material }\end{array}$ & Control & W2 & W3 & W5 \\
\hline $\begin{array}{l}\text { Scots pine } \\
\text { sapwood }\end{array}$ & 210.5 & 73 & 115.8 & 83.1 \\
\hline Poplar plywood & 533.4 & 344.9 & 619.4 & 385.9 \\
\hline $\begin{array}{l}\text { Spruce } \\
\text { plywood }\end{array}$ & 436.6 & 307.4 & 82.8 & 71.7 \\
\hline $\begin{array}{l}\text { Maritime pine } \\
\text { plywood }\end{array}$ & 142.1 & 130.0 & 50.5 & 36.7 \\
\hline Birch plywood & 750.4 & 505.9 & 380.2 & 189.9 \\
\hline OSB & 58.6 & 266.6 & 1202.2 & 189.3 \\
\hline MDF & 91.2 & 1524.2 & 3582.9 & 1636.1 \\
\hline
\end{tabular}


Cycle A

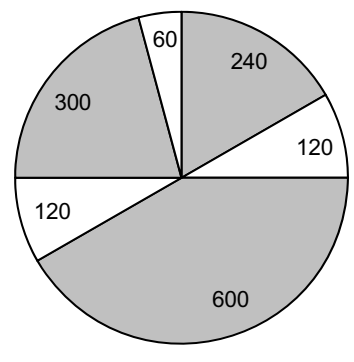

O Spray nozzles on
Cycle B

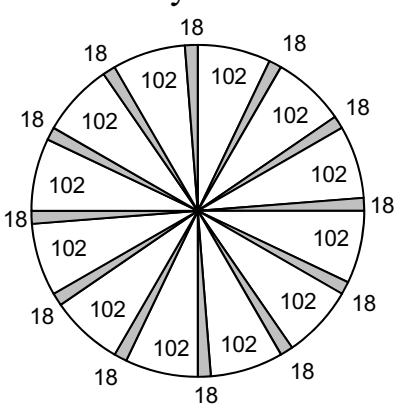

O Spray nozzles off 


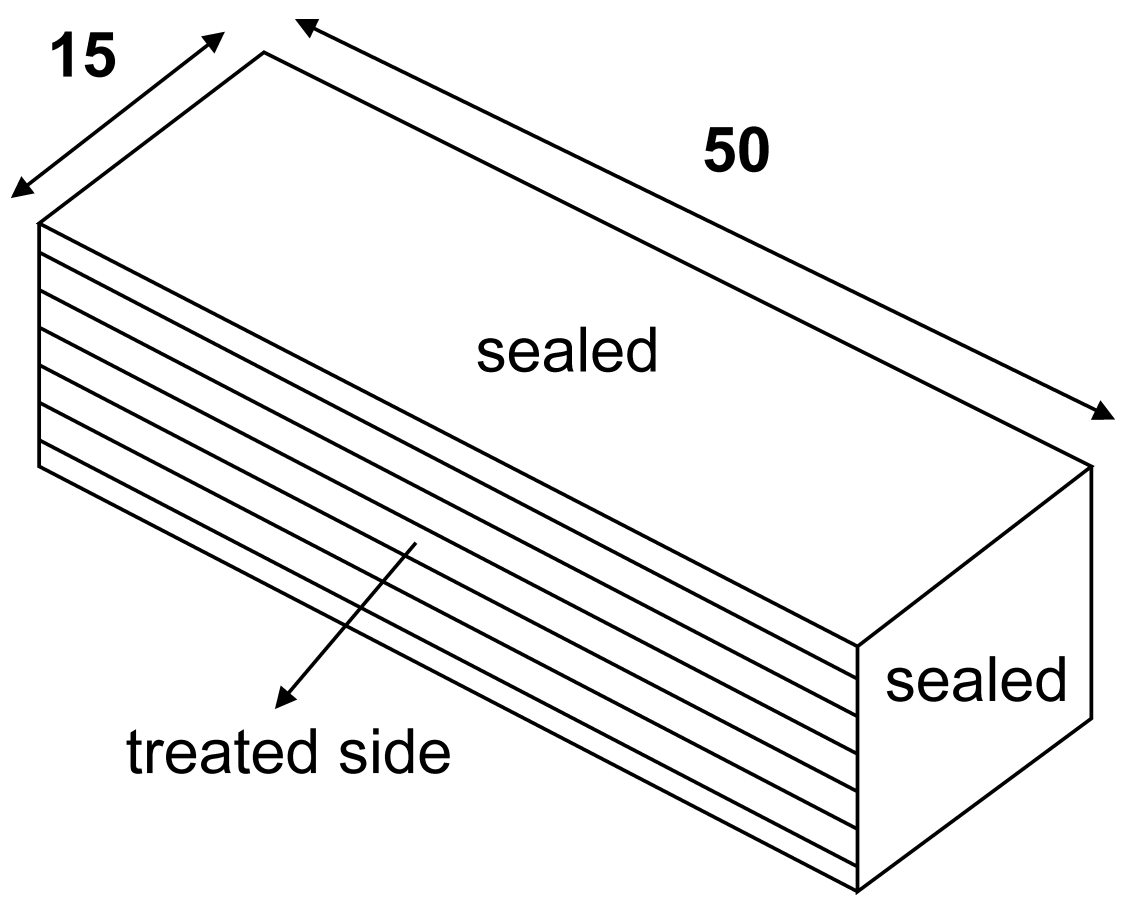




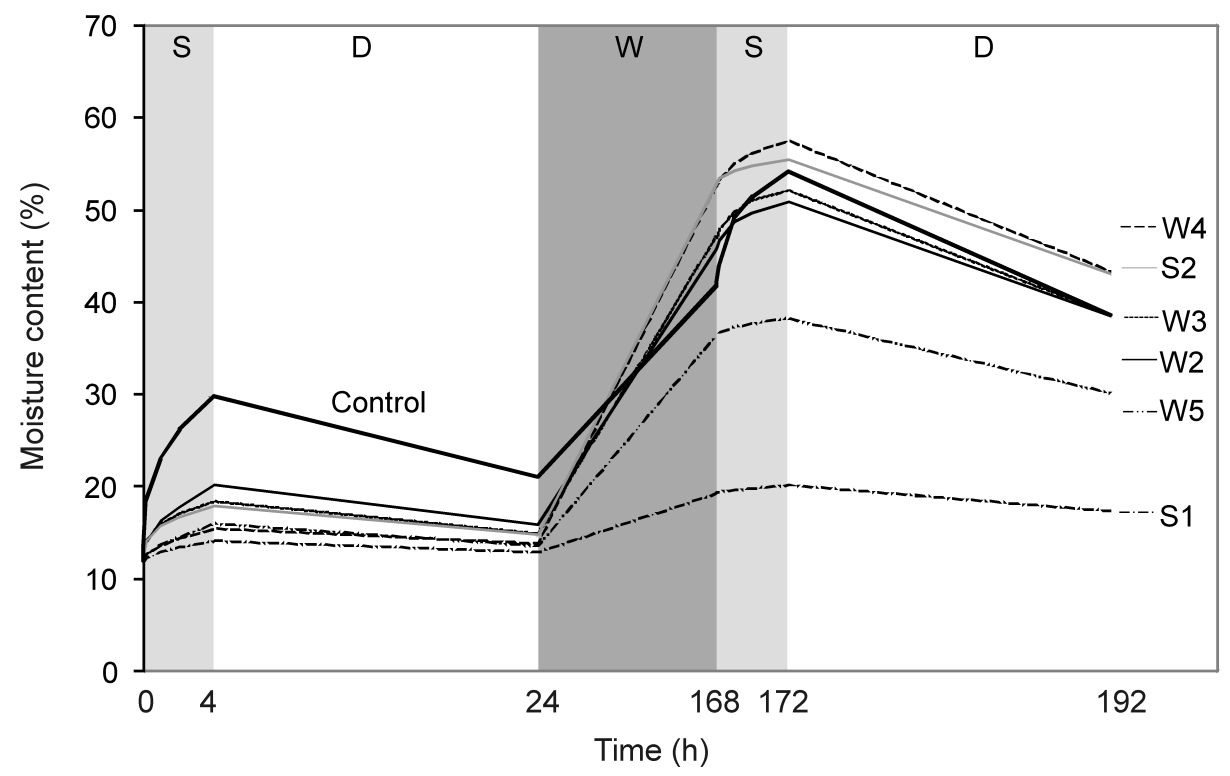

Fig3 


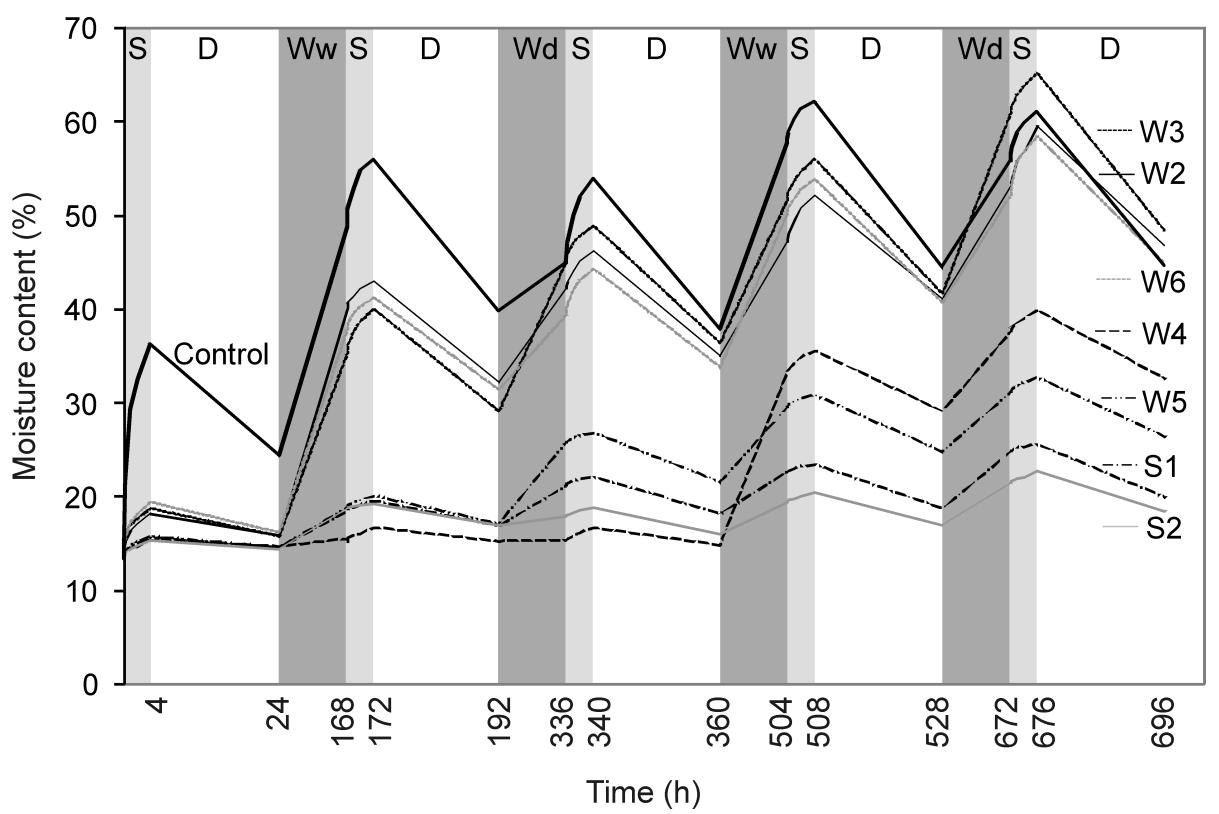




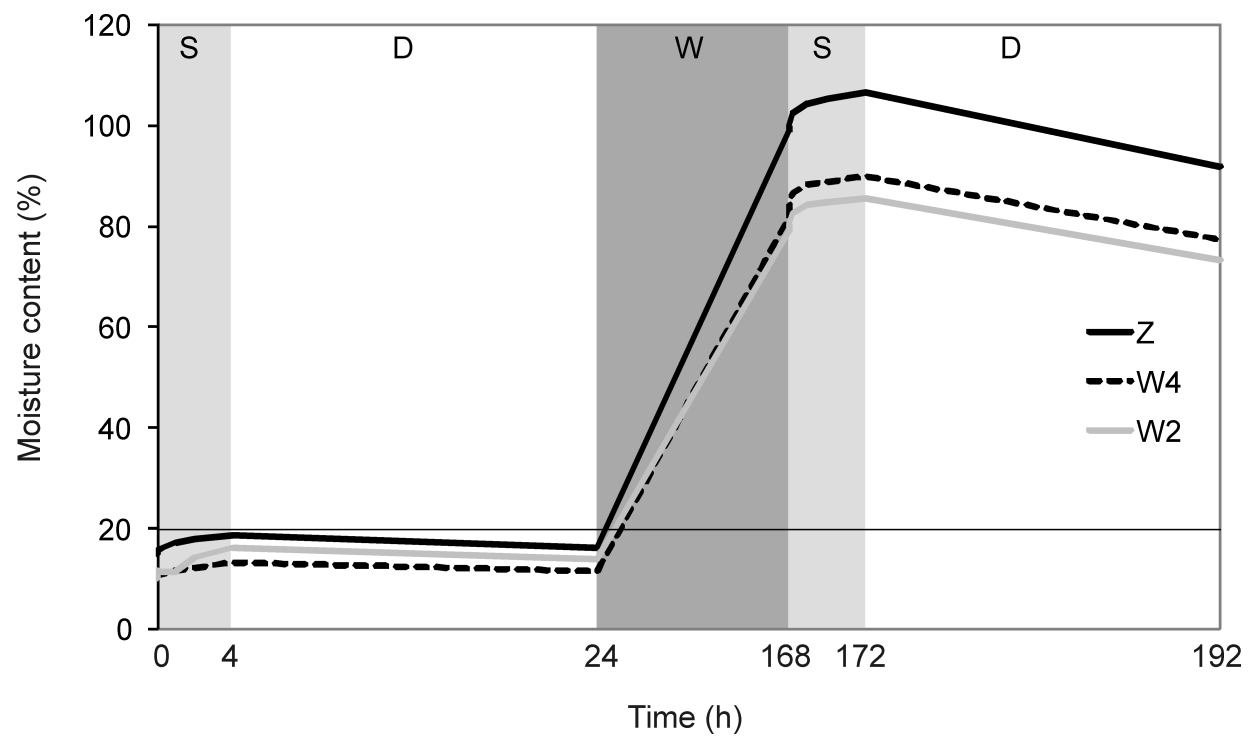

Fig5 

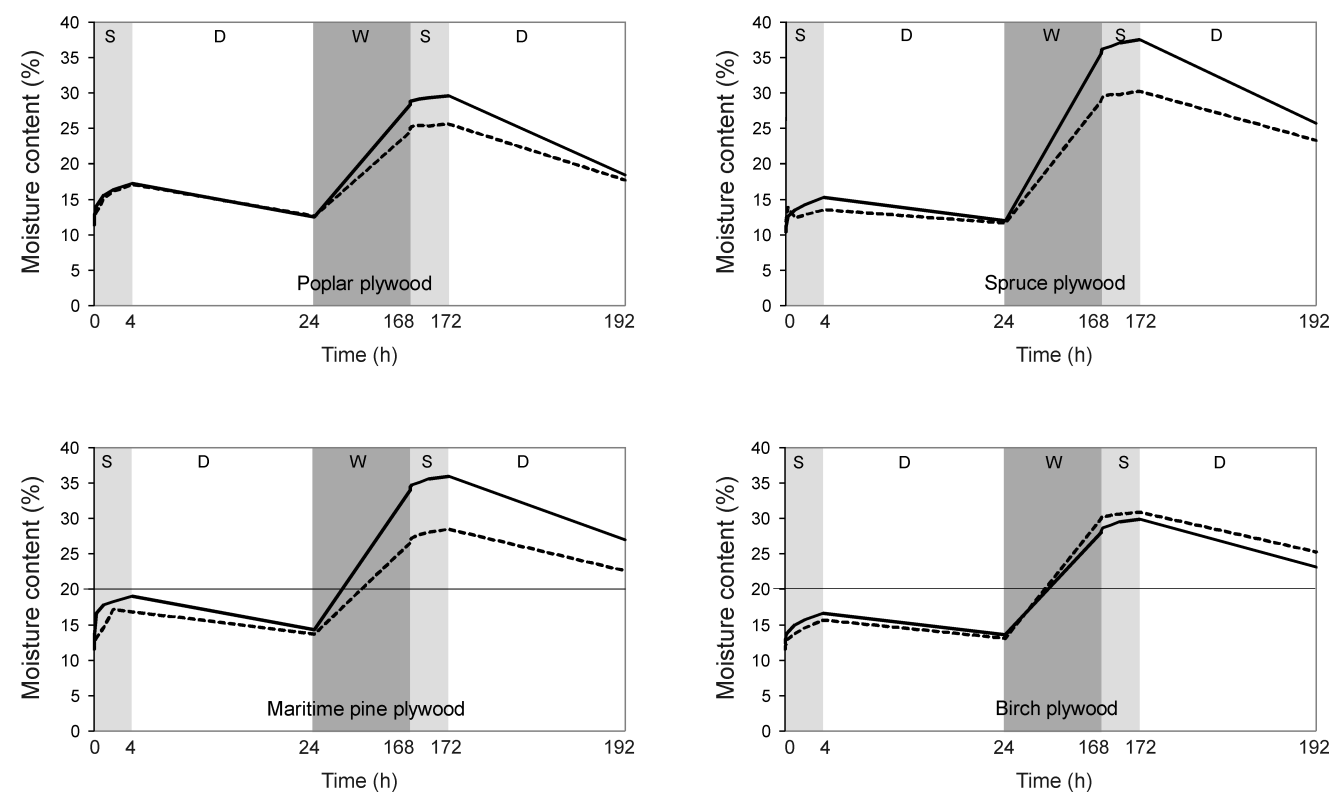
a
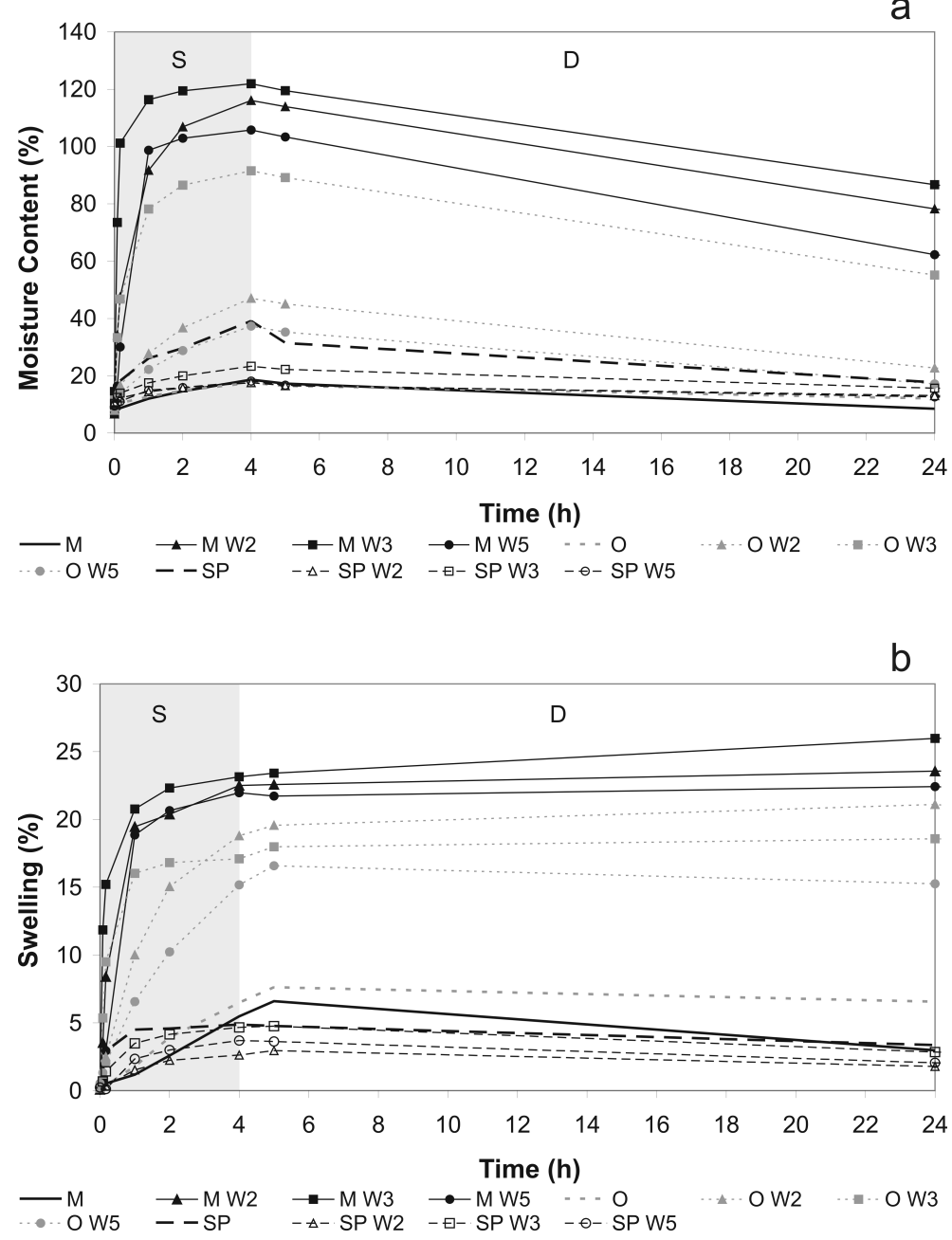


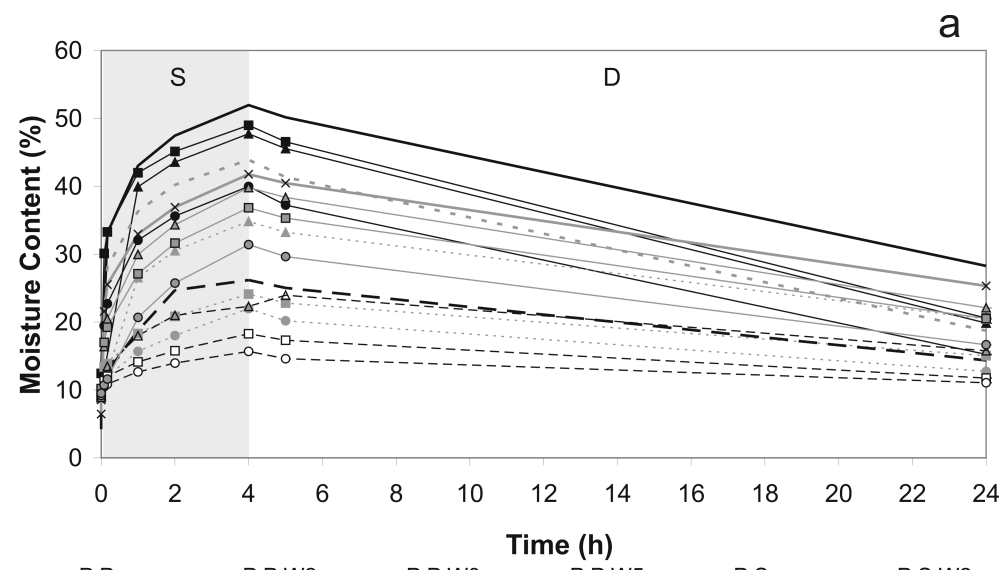

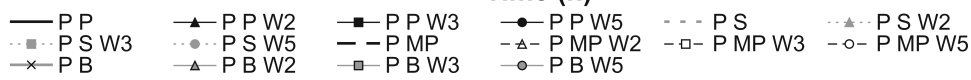

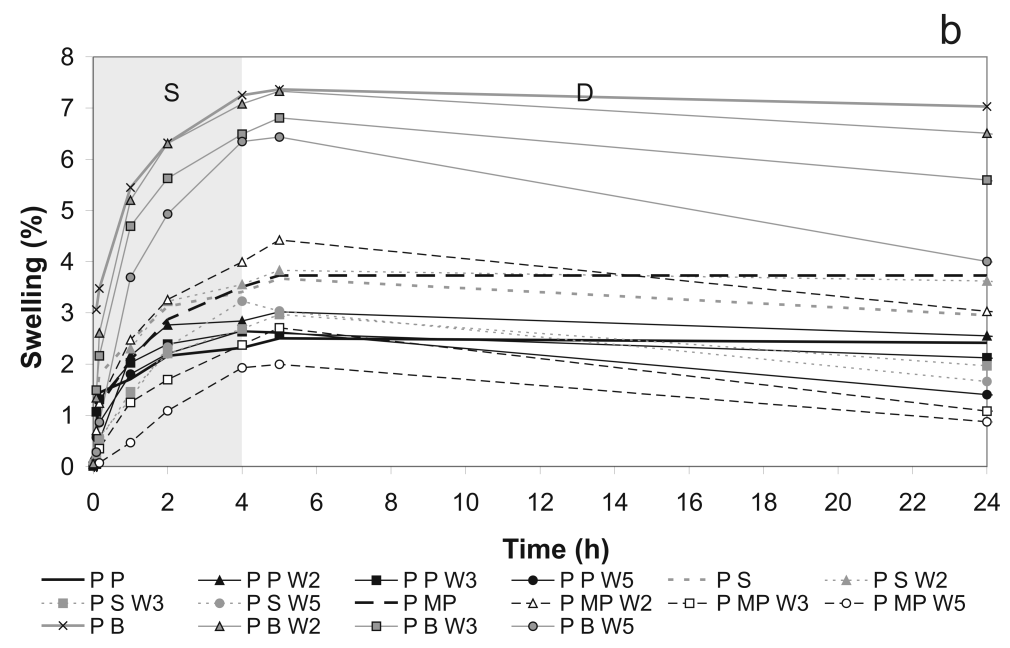

